АРОЧНАЯ ЭСТАКАДА С МАГНИТНЫМ ИЛИ ЭЛЕКТРОМАГНИТНЫМ ПОДВЕШИВАНИЕМ МАЛОГАБАРИТНЫХ ТРАНСПОРТНЫХ МОДУЛЕЙ

Е. Ю. Сундуков ${ }^{-1}$, С. М. Кочергин ${ }^{-2}$, Л. Ф. Селиванов ${ }^{-3}$

${ }^{1-}$ Сыктывкарский лесной институт (филиал)

${ }^{2-}$ Санкт-Петербургский государственный лесотехнический университет имени С. М. Кирова (Сыктывкар, Россия)

${ }^{3-}$ пенсионер (с. Ижма, Республика Коми, Россия)

\title{
ARCH ELEVATED TRACK WITH MAGNETIC OR ELECTROMAGNETIC SUSPENSION OF SMALL-SIZED TRANSPORT MODULES
}

E. Yu. Sundukov ${ }^{-1}$, S. M. Kochergin ${ }^{-2}$, L. F. Selivanov ${ }^{-3}$ ${ }^{1-}$ The Syktyvkar forest institute (branch) of FGVOU VO ${ }^{2-}$ The St. Petersburg state forest university of S. M. Kirov (Syktyvkar, Russia)

${ }^{3-}$ pensioner (village Izhma, Komi Republic, Russia)

\begin{abstract}
Введение
Предлагаются технологии малогабаритного магнитолевитационного транспорта для Севера России. В частности, эстакады арочного типа позволят обеспечить защиту путепроводов и транспортных средств от повышения уровней водотоков и других природных явлений. Особенностью таких эстакад является перемещение транспортного средства относительно внутренней верхней поверхности эстакады - «езда по потолку». Для преодоления водных преград арочные эстакады могут подвешиваться на тросах (канатах) между высотными опорами. Для преодоления болот такие эстакады могут устанавливаться на гати и понтоны.
\end{abstract}




\section{Арочная эстакада и возможные варианты её применения}
В условиях
Севера
России
путепроводы

магнитолевитационных систем следует строить в эстакадном исполнении. Использование малогабаритных транспортных модулей потребует, соответственно, и конструктивные элементы эстакад меньших размеров. Эстакады традиционных типов обеспечивают защиту путевых сооружений и движущихся транспортных средств от повышения уровня водотоков, а также снежных заносов. Однако, для выполнения этих функций зачастую требуется поднятие путепровода на значительную высоту, что, в свою очередь, вызывает явление парусности и требует защиты от порывов ветра, а также исключение возможности переворачивания транспортных модулей.

Защитить путепровод и малогабаритные транспортные средства от атмосферных явлений позволит эстакада арочного типа. Эстакада арочного типа представляет собой ограничитель перемещений, имеющий арку в поперечном сечении, на внутренней поверхности которого размещены либо рельсы из сверхпроводящего материала, либо витки статорной обмотки, обеспечивающие магнитное или электромагнитное подвешивание транспортного модуля, оборудованного магнитными источниками, а также витки статорной обмотки ускоряющего электромагнита,

Такая эстакада может использоваться для перемещения:

- малогабаритных грузовых и пассажирских транспортных модулей, оборудованных источниками магнитного поля;

— автомобилей с нормальными габаритами, на верней части которых закреплены источники магнитного поля;

- специальных емкостей (бочек, баллонов, миницистерн и др.) для перевозки жидких углеводородов.

\section{Транспортировка углеводородов с использованием арочной эстакады}

Разработка газоконденсатных месторождений на полуострове Ямал обуславливает необходимость увеличения объемов транспортировки сжиженного природного газа (СПГ), в том числе и сухопутным способом. Сухопутная транспортировка углеводородов осуществляется либо по трубопроводам, либо в 
железнодорожных цистернах. Для сжижения газ охлаждается до температуры $-163{ }^{\circ} \mathrm{C}$ и сжимается в 600 раз на специальных заводах. В настоящее время к крупнейшим месторождениям природного газа - Новопортовскому и Южно-Тамбейскому, где планируется строительство завода по производству СПГ, трубопроводы и железнодорожные пути не проложены. Мощность самого завода по производству СПГ составит 16,5 млн тонн в год.

Предлагается на полуострове Ямал построить малогабаритные эстакадные путепроводы арочного типа на основе магнитной (электромагнитной) подвески от поселков Сабетта и Новый Порт до железнодорожных станций Бованенково и Паюта, соответственно. На указанных станциях построить терминалы для перегрузки наполненных миницистерн с малогабаритной эстакады в специальные вагоны, пустых - из вагонов на эстакаду. Перемещение магнитноподвешенных миницистерн относительно эстакады будет осуществляться в автоматическом режиме.

\section{Заключение}

При помощи малогабаритного эстакадного магнитолевитационного транспорта могут быть реализованы транспортные связи от газоперерабатывающих заводов на побережье Обской губы к железнодорожной линии Обская Бованенково.

\section{Библиографический список}

1. Антонов Ю. Ф., Зайцев А. А. Магнитолевитационная транспортная технология / под ред. В. А. Гапановича. - М.: Физматлит, 2014. - 476 с.

2. Киселенко А. Н., Сундуков Е. Ю. Возможности магнитнолевитационного транспорта для повышения связности транспортной сети Европейской и Приуральской Арктики и в логистических процессах // Транспортные системы и технологии: сетевой электронный журнал / Петербургский государственный университет путей сообщения. - СПб: ФГБОУ ВПО ПГУПС, 2016. - № 2 (4). - C. 14-17. - URL: http://www.transsyst.ru/files/2kiselenko-an-syndykov-ey-pdf.pdf 
3. Вербо А. М. Инновации в области морской перевозки сжиженного природного газа // Горный информационноаналитический бюллетень (научно-технический журнал). - М.: Горная книга, 2008. - №3. - С. 38-44.

4. U1 168039 RU 6 B 60 L 13/10 Транспортная система с шаговым электромагнитным двигателем и колесными опорами / Сундуков Е. Ю., Малащук П. А., Тарабукина Н. А. - 2016100487; Заявл. 11.01.2016 // Полезные модели (Заявки и патенты). - 2017. - № 2.

5. C2 2199451 RU 6 В 60 L 13/00 Ограничитель перемещений транспортного средства / Евдокимов Б. П., Сундуков Е. Ю., Свойкин В. Ф. - 99123534/28; Заявл. 09.11.99// Изобретения (Заявки и патенты). - 2003. - № 64.

6. C1 2123946 RU 6 B 60 L 13/10 Транспортная система / Сундуков Е. Ю. - 961245/28; Заявл. 27.12.96 // Изобретения (Заявки и патенты). - 1998. - № 36.

\section{Сведения об авторах:}

СУНДУКОВ Евгений Юрьевич

E-mail: jek-sun@mail.ru

КОЧЕРГИН Сергей Михайлович

E-mail: atpp@sfi.komi.com

СЕЛИВАНОВ Леонид Фёдорович

E-mail:1.seliwanov@yandex.ru

\section{Information of author:}

Evgeny SUNDUKOV

E-mail: jek-sun@mail.ru

Sergej KOCHERGIN

E-mail: atpp@sfi.komi.com

Leonid SELIVANOV

E-mail: 1.seliwanov@yandex.ru 